\title{
Master Teacher Award
}

Published online: 5 January 2018

(C) International Association of Medical Science Educators 2018

This annual award was established to honor an IAMSE member who, over the course of many years, has consistently demonstrated extraordinary excellence in teaching both at his/her institution and within IAMSE. Any teaching can be recognized, but nominations of members who have been active teachers at the annual IAMSE meetings or web seminars are particularly encouraged.

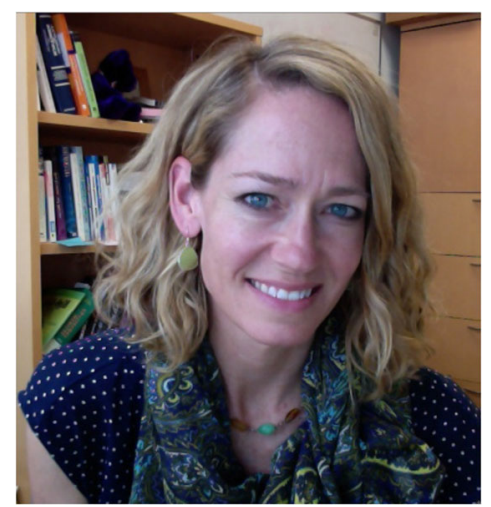

\section{Award Winner-Tracy Fulton, PhD}

Tracy Fulton has spent the last 23 years at the University of California, San Francisco (UCSF), where she earned her $\mathrm{PhD}$ and is professor of Biochemistry and Biophysics. As a grad student, while studying telomerase in yeast, she explored her love for teaching as an adult literacy tutor, an animal museum docent, a K-5 classroom helper, and a TA for dental school biochemistry. She settled on professional school education as her target path and since joining the faculty in 2000 has directed and taught in courses in the Schools of Medicine, Pharmacy, and Dentistry, earning many teaching awards from her students and peers. In the inaugural Bridges medical curriculum, Tracy directs the REGulatioN (Renal, Endocrine, GI, Nutrition) block, and chaired two working groups to establish an assessment system that emphasizes open-ended questions. Tracy is active in IAMSE, past secretary for the Association of Biochemistry Educators (ABE), and co-chairs the NBME Test Material Development Committee for pharmacology and biochemistry. Tracy is on the leadership team for MedU Science, a project involving many IAMSE members focused on use of basic science concepts in clerkship clinical decision-making. She is working with IAMSE/ABE colleagues Janet Lindsley and Tina Cowan on an NBME task force to implement a nationally supported metabolic map as a reference on Step exams. Tracy's involvement in IAMSE has been pivotal in her professional development; she thanks the organization's leadership and membership for many of her most rewarding experiences, collaborations, and friendships in education. 